\title{
Ionized Intracellular Calcium Concentration Predicts Excitotoxic Neuronal Death: Observations with Low-Affinity Fluorescent Calcium Indicators
}

\author{
Krzysztof Hyrc, ${ }^{1}$ Shawn D. Handran, ${ }^{1}$ Steven M. Rothman, ${ }^{1,2}$ and Mark P. Goldberg ${ }^{1}$ \\ ${ }^{1}$ Center for the Study of Nervous System Injury and Departments of Neurology and Anatomy and Neurobiology, \\ Washington University School of Medicine, St. Louis, Missouri 63110, and 2Department of Pediatric Neurology, St. Louis \\ Children's Hospital, St. Louis, Missouri 63110
}

Cytosolic calcium $\left(\left[\mathrm{Ca}^{2+}\right]_{\mathrm{i}}\right)$ is an important mediator of neuronal signal transduction, participating in diverse biochemical reactions that elicit changes in synaptic efficacy, metabolic rate, and gene transcription. Excessive $\left[\mathrm{Ca}^{2+}\right]_{i}$ also has been implicated as a cause of acute neuronal injury, although measurement of $\left[\mathrm{Ca}^{2+}\right]_{\mathrm{i}}$ in living neurons by fluorescent calcium indicators has not consistently demonstrated a correlation between $\left[\mathrm{Ca}^{2+}\right]_{i}$ and the likelihood of neuronal death after a variety of potentially lethal insults. Using fluorescence videomicroscopy and microinjected calcium indicators, we measured $\left[\mathrm{Ca}^{2+}\right]_{\mathrm{i}}$ in cultured cortical neurons during intense activation with either NMDA $(300 \mu \mathrm{M})$ or AMPA $(450 \mu \mathrm{M})$. At these concentrations NMDA killed $>80 \%$ of the cultured neurons by the next day, whereas neuronal death from AMPA was $<20 \%$. Using the conventional calcium indicator, fura-2/AM, we estimated $\left[\mathrm{Ca}^{2+}\right]_{i}$ elevations to be $\sim 300-400 \mathrm{~nm}$ during exposure to either glutamate ago- nist. In contrast, indicators with lower affinity for calcium, benzothiazole coumarin (BTC), and fura-2/dextran reported $\left[\mathrm{Ca}^{2+}\right]_{\mathrm{i}}$ levels $>5 \mu \mathrm{M}$ during lethal NMDA exposure, but $\left[\mathrm{Ca}^{2+}\right]_{\mathrm{i}}$ levels were $<1.5 \mu \mathrm{M}$ during nonlethal activation of AMPA receptors or voltage-gated calcium channels. Fura-2 reported $\left[\mathrm{Ca}^{2+}\right]_{\mathrm{i}}$ responses during brief exposure to glutamate, NMDA, AMPA, kainate, and elevated extracellular $\mathrm{K}^{+}$between 0.5 and $1 \mu \mathrm{M}$. With the use of BTC, only NMDA and glutamate exposures resulted in micromolar $\left[\mathrm{Ca}^{2+}\right]_{\mathrm{i}}$ levels. Neurotoxic glutamate receptor activation is associated with sustained, micromolar $\left[\mathrm{Ca}^{2+}\right]_{\mathrm{i}}$ elevation. The widely used calcium indicator fura-2 selectively underestimates $\left[\mathrm{Ca}^{2+}\right]_{i}$, depending on the route of entry, even at levels that appear to be within its range of detection.

Key words: AMPA; calcium; excitotoxicity; fura-2; glutamate; kainate; NMDA; videomicroscopy
Neuronal injury in stroke or trauma may be mediated by excessive stimulation of glutamate receptors (Rothman and Olney, 1986; Choi, 1992). Studies using primary neuronal culture systems have shown that cultured neurons are selectively vulnerable to brief applications of glutamate (Rothman, 1985; Choi et al., 1987) or to selective agonists of the NMDA class of glutamate receptors (Rothman, 1985; Choi et al., 1988; Hartley and Choi, 1989). In contrast, prolonged activation of the AMPA or kainate receptors is required to produce neurotoxicity (Koh et al., 1990).

Schanne and colleagues (1979) originally described the dependence of extracellular calcium in hepatocyte toxicity, which provided a potential mechanism for neuronal toxicity with the subsequent discovery that glutamate receptor activation produced neuronal calcium influx (Connor et al., 1987, 1988; Murphy et al., 1987). Additional studies by other investigators led to the hypothesis that calcium entry was responsible for excitotoxic neuronal injury (Choi, 1987) (for review, see Dubinsky, 1993a). A corre-

\footnotetext{
Received April 18, 1997; revised June 2, 1997; accepted June 12, 1997.

This work was supported by National Institutes of Health Grants R01 19988 (S.M.R.), P20 NS32568 (S.M.R.), R29 NS32140 (M.P.G.), and P01 NS32626 (M.P.G.) and was done during the tenure of a Grant-in-Aid Award (to M.P.G.) from the American Heart Association and William Randolph Hearst Foundation. Dr. Hyrc is on leave from the Institute of Molecular Biology, Jagiellonian University, Krakow, Poland. We thank Sandy P. Althomsons for expert assistance with cell cultures, Joanna Bownik for performing spectrofluorimetric experiments, and Richard S. Hotchkiss for assistance with confocal microscopy.

K.H. and S.D.H. contributed equally to this work.

Correspondence should be addressed to Dr. Mark P. Goldberg, Department of Neurology, Box 8111, 660 South Euclid Avenue, St. Louis, MO 63110.

Copyright (C) 1997 Society for Neuroscience $0270-6474 / 97 / 176669-09 \$ 05.00 / 0$
}

lation between intracellular calcium levels and glutamate toxicity was suggested by the dependence of the latter on extracellular calcium (Choi, 1987; Rothman et al., 1987). Studies with radioactive ${ }^{45} \mathrm{Ca}^{2+}$ isotope demonstrated substantial calcium entry during toxic NMDA receptor activation but much lower ${ }^{45} \mathrm{Ca}^{2+}$ influx during nonlethal AMPA treatment (Marcoux et al., 1988; Hartley et al., 1993; Eimerl and Schramm, 1994; Lu et al., 1996). The study by Hartley and coworkers (1993) suggested that a direct relationship existed between calcium accumulation and subsequent death in neurons exposed to NMDA. Although previous studies using fluorescent intracellular calcium indicators have noted that lethal excitotoxic insults may be followed by prolonged or delayed $\left[\mathrm{Ca}^{2+}\right]_{\mathrm{i}}$ elevation (Ogura et al., 1988; de Erausquin et al., 1990; Randall and Thayer, 1992; Dubinsky, 1993b; Tymianski et al., 1993a; Limbrick et al., 1995), such indicators have failed to demonstrate a consistent difference between intracellular free calcium concentration $\left(\left[\mathrm{Ca}^{2+}\right]_{\mathrm{i}}\right)$ in cells during lethal and nonlethal challenges (de Erausquin et al., 1990; Michaels and Rothman, 1990; Tymianski et al., 1993a).

One potential interpretation of these results is that there is not a direct relationship between the magnitude of acute $\left[\mathrm{Ca}^{2+}\right]_{i}$ elevation and the extent of subsequent neuronal death. Another possibility is that current methods of $\left[\mathrm{Ca}^{2+}\right]_{\mathrm{i}}$ measurement fail to distinguish toxic levels of $\left[\mathrm{Ca}^{2+}\right]_{i}$. In the present study we examine the hypothesis that conventional, high-affinity calcium indicators (e.g., fura-2) are unable to measure accurately the $\left[\mathrm{Ca}^{2+}\right]_{i}$ in the micromolar range and therefore fail to detect differences in $\left[\mathrm{Ca}^{2+}\right]_{\mathrm{i}}$ between lethal and nonlethal excitotoxic exposures. We 
used fura-2/AM ester, fura- $2 / \mathrm{K}^{+}$salt, fura-2/dextran, or a benzothiazole coumarin-based indicator, BTC, to determine $\left[\mathrm{Ca}^{2+}\right]_{\mathrm{i}}$ in neurons subjected to lethal and nonlethal challenges. The low affinity of BTC for calcium $\left(K_{\mathrm{D}} \sim 7-26 \mu \mathrm{M}\right)$ allows detection of $\left[\mathrm{Ca}^{2+}\right]_{\mathrm{i}}$ in the micromolar range (Iatridou et al., 1994; Z hao et al., 1996).

Some of the information in this paper has been published in abstract form (Hyrc et al., 1996, 1997).

\section{MATERIALS AND METHODS}

Neuronal cultures. We used dissociated neocortical neurons prepared from brains of embryonic Swiss-Webster mice at gestational days 15-16 (Rose et al., 1993). Gravid mice were anesthetized with halothane, and the uteri were removed under sterile conditions. After the embryo brains were removed, the neocortices were digested with trypsin $(0.9 \%)$ and separated into a single-cell suspension by mechanical trituration through Pasteur pipettes. Cells were plated (0.5 hemisphere per dish) onto glass-bottom $35 \mathrm{~mm}$ dishes (Mattek, Ashland, MA) previously coated with a mixture of poly-D-lysine $(0.5 \mathrm{mg} / \mathrm{ml})$ and laminin $(4 \mu \mathrm{g} / \mathrm{ml})$. The culture medium consisted of Eagle's Minimal Essential Medium containing $25 \mathrm{~mm}$ glucose, $2 \mathrm{~mm}$ glutamine, $5 \%$ fetal bovine serum, and $5 \%$ horse serum. After $8 \mathrm{~d}$ in vitro, the proliferation of non-neuronal cells was inhibited by the addition of $10 \mu \mathrm{M}$ cytosine arabinoside. Cultures were fed twice weekly and were used 14-17 d after plating.

Excitotoxin exposure. Cells were exposed to elevated $\mathrm{KCl}(50 \mathrm{mM})$ or to glutamate receptor agonists (300 $\mu \mathrm{M}$ NMDA or glutamate; $450 \mu \mathrm{M}$ AMPA or kainate) at room temperature in a HEPES- and bicarbonatebuffered salt solution (HBBSS) containing (in $\mathrm{mM}$ ): $116 \mathrm{NaCl}, 5.4 \mathrm{KCl}$, $1.8 \mathrm{CaCl}_{2}, 0.8 \mathrm{MgSO}_{4}, 1 \mathrm{NaH}_{2} \mathrm{PO}_{4}, 25 \mathrm{NaHCO}_{3}, 12 \mathrm{HEPES}$, and 5.5 D-glucose, pH $7.45 \pm 0.2$. Bicarbonate was included in the experimental solution to minimize glutamate receptor-mediated intracellular acidification (Canzoniero et al., 1996). The NMDA receptor antagonist MK$801(10 \mu \mathrm{M})$ was included in all treatments except NMDA and glutamate to prevent secondary activation of NMDA receptors. For toxicity assessment, cultures subjected to experimental treatments were washed with HBBSS containing $10 \mu \mathrm{M}$ MK-801 and returned to the incubator. Neuronal survival was determined $20-28 \mathrm{hr}$ later by $0.4 \%$ trypan blue exclusion. The fraction of trypan blue-positive neurons in each culture dish was calculated in 5-10 random fields containing 20-50 neurons.

Calcium indicators. Cytosolic calcium determination was performed with fluorescent calcium indicators: fura-2/AM ester, fura- $2 / \mathrm{K}^{+}$salt fura-2 coupled to dextran [fura-2/dextran; molecular weight (MW) 3000], and benzothiazole coumarin (BTC) (Iatridou et al., 1994; Konishi and Watanabe, 1995). All indicators were purchased from Molecular Probes (Eugene, OR)

Fura-2/AM $(6 \mu \mathrm{M})$ was bath-loaded into neurons for $30 \mathrm{~min}$ in the presence of $0.12 \%$ of Pluronic 127 , followed by another 30 min incubation at $37^{\circ} \mathrm{C}$ to allow for hydrolysis of the AM ester. All of the other indicators were loaded into the neurons by transient application of patch micropipettes in whole-cell recording configuration. We used 2-6 $\mathrm{M} \Omega$ micropipettes fabricated from $1.2 \mathrm{~mm}$ outer diameter, thin-wall glass tubing (World Precision Instruments, Sarasota, FL), using a two-stage microelectrode puller (Sutter P-87, Sutter Instrument, Novato, CA). The tip of the micropipette was backfilled by capillary action with $500 \mu \mathrm{M}$ calcium indicator dissolved in an intracellular solution. This solution contained (in $\mathrm{mM}$ ): $115 \mathrm{~K}^{+}$gluconate, $20 \mathrm{KCl}, 10 \mathrm{HEPES}$, and 2 $\mathrm{Mg}$-ATP, $\mathrm{pH} 7.4$; the remainder of the micropipette was filled with intracellular solution alone.

We used a standard bridge amplifier (M707, World Precision Instruments) for monitoring resting membrane potential in the whole-cell configuration (Hamill et al., 1981). The neuron was filled with indicator for $60 \mathrm{sec}$ by diffusion, after which the micropipette was withdrawn carefully. All neurons were incubated for $30 \mathrm{~min}$ at room temperature after pipette removal, and only those that maintained their preinjection morphology and retained dye were used for $\left[\mathrm{Ca}^{2+}\right]_{\mathrm{i}}$ imaging $(n=289$ neurons of 599 attempts, for an approximate success rate of $48 \%$ ). In our hands, cultured cortical neurons tolerated indicator injection better with patch micropipettes than with high-impedance microelectrodes. In preliminary experiments the loading conditions were selected to provide comparable fluorescence intensity to that of bath-loaded fura-2/AM, using rapid diffusion $(60 \mathrm{sec})$ and the smallest micropipette indicator concentration $(500 \mu \mathrm{M})$. Previous studies indicate that the intracellular concentration of indicator is actually much lower than that of the pipette, because considerably longer periods generally are required for dye equilibration from patch pipettes (Pusch and Neher, 1988; Sala and Hernandez-Cruz, 1990).

Calcium imaging. Calcium measurements were performed with standard ratio imaging techniques (Grynkiewicz et al., 1985). Indicator-filled neurons were imaged on an inverted microscope (Nikon Diaphot, Nikon, Melville, NY), using a $40 \times, 1.3$ numerical aperture (NA) fluorite oil immersion objective (Nikon) and an intensified charge-coupled device (ICCD) camera (Hamamatsu Photonics, Oak Brook, IL) operating at moderate gain (typical settings 0.5-3). A $75 \mathrm{~W}$ xenon arc lamp was used to provide fluorescence excitation. Ratio images were obtained by acquiring pairs of images at alternate excitation wavelengths $(340 / 380 \mathrm{~nm}$ for fura- 2 and $400 / 485 \mathrm{~nm}$ for BTC) and filtering the emission at $530 \mathrm{~nm}$. Image acquisition and processing were controlled by a personal computer connected to the camera and filter wheel (MetaFluor, Universal Imaging Corporation, West Chester, PA). Image pairs were captured and digitized every $10 \mathrm{sec}$, and the images at individual wavelengths were averaged over four frames. We corrected for background fluorescence by imaging a field lacking an injected neuron and subtracting the paired images from the images of the indicator-loaded neuron.

We calculated actual $\left[\mathrm{Ca}^{2+}\right]_{i}$ in regions of interest in individual neurons with the formula:

$$
\left[\mathrm{Ca}^{2+}\right]_{\mathrm{i}}=K_{\mathrm{D}} B\left(R-R_{\min }\right) /\left(R_{\max }-R\right),
$$

where $K_{\mathrm{D}}$ is the indicator's dissociation constant for $\mathrm{Ca}^{2+} ; R$ is ratio of fluorescence intensity at two different wavelengths $(340 / 380 \mathrm{~nm}$ for fura- 2 and $400 / 485 \mathrm{~nm}$ for BTC); $R_{\max }$ and $R_{\min }$ are the ratios at saturating $\mathrm{Ca}^{2+}$ and zero $\mathrm{Ca}^{2+}$, respectively; and $B$ is the ratio of the fluorescence intensity of the second excitation wavelength at zero and saturating $\mathrm{Ca}^{2+}$ (Grynkiewicz et al., 1985). $R_{\min }, R_{\max }$, and $B$ for all indicators were determined for our system by imaging large droplets $(100$ $\mu l)$ evenly filling the microscopic field that contained 0 and $39.6 \mu \mathrm{M} \mathrm{Ca}^{2+}$ and $25 \mu \mathrm{M}$ fura- $2 / \mathrm{K}^{+}$or fura-2/dextran (Calcium Calibration Buffer Kit I with magnesium, Molecular Probes). $R_{\max }$ for $\mathrm{BTC}$ was determined with a $1 \mathrm{mM} \mathrm{Ca}^{2+}$ standard solution (Molecular Probes). The concentration of indicators in the calibration solution was selected to provide similar fluorescence intensity to that of dye-loaded neurons.

Spectrofluorimetric indicator calibration. We determined the $K_{\mathrm{D}}$ values of the indicators used in this study with a spectrofluorimeter (PerkinElmer LS 50, Perkin-Elmer, Norwalk, CT). We recorded the spectra of the indicator solution $(2-5 \mu \mathrm{M})$ in calibrating buffers containing (in $\mathrm{mM}$ ): $100 \mathrm{KCl}, 1 \mathrm{Mg}^{2+}$, and $10 \mathrm{MOPS}$, with $\left[\mathrm{Ca}^{2+}\right]$ ranging from 0 to $39 \mu \mathrm{M}$ (Calcium Calibration Buffer Kit I with $\mathrm{Mg}^{2+}$, Molecular Probes). The spectra were excited over the range 320-400 $\mathrm{nm}$ for fura-2 and fura-2/ dextran and 380-500 $\mathrm{nm}$ for BTC. Emission was detected at $525 \mathrm{~nm}$, and excitation slits were set at $6-10 \mathrm{~nm}$. All calibrations were done at room temperature.

The increasing calcium concentrations were obtained by cross-diluting $10 \mathrm{~mm}$ EGTA and $10 \mathrm{~mm}$ CaEGTA solutions, using the protocol provided by Molecular Probes. Free calcium concentrations were calculated from the equation: $\left[\mathrm{Ca}^{2+}\right]=K_{\mathrm{D}} \cdot[\mathrm{CaEGTA}] /[$ EGTA] . Buffers containing more than the $40 \mu \mathrm{M}\left[\mathrm{Ca}^{2+}\right]$ necessary to saturate BTC were prepared by adding aliquots of $10 \mathrm{mM} \mathrm{CaCl}_{2}$ stock solution to $10 \mathrm{~mm}$ CaEGTA solution. Subsequently, free calcium concentration was calculated with the method described by Tsien and Pozzan (1989). The $\mathrm{pH}$ of calibration buffers was adjusted to 7.2, and the dissociation constants of EGTA for $\mathrm{Ca}^{2+}$ and $\mathrm{Mg}^{2+}$ used in the calculations were assumed to be $150.5 \mathrm{~nm}$ and $19.7 \mathrm{~mm}$, respectively (Tsien and Pozzan, 1989).

The indicator $K_{\mathrm{D}}$ values were determined from the spectra by first calculating the ratios of indicator emission intensities over a range of $\left[\mathrm{Ca}^{2+}\right]$ at appropriate excitation wavelengths (340/380 for fura-2 and fura-2/dextran and $400 / 485 \mathrm{~nm}$ for BTC). We used the basic equation relating ratio $(R), K_{\mathrm{D}}, F$, and $\left[\mathrm{Ca}^{2+}\right]:\left[\mathrm{Ca}^{2+}\right]=K_{\mathrm{D}} B\left(R-R_{\min }\right) /\left(R_{\max }\right.$ $-R)$ and regressed $\log \left[\mathrm{Ca}^{2+}\right]$ against $\log B\left(R-R_{\min }\right) /\left(R_{\max }-R\right)$ to obtain each $K_{\mathrm{D}}$ (Grynkiewicz et al., 1985).

We observed a $K_{\mathrm{D}}$ value for fura-2 $(0.24 \mu \mathrm{M}$; Fig. 1$)$, which was close to the previously published value of $0.22 \mu \mathrm{M}$ (Grynkiewicz et al., 1985). Our $K_{\mathrm{D}}$ for BTC $(15.2 \mu \mathrm{M}$; Fig. 1) lies between the values reported by Iatridou et al. (1994) $(7 \mu \mathrm{M})$ and Zhao et al. (1996) $(26 \mu \mathrm{M})$. Because the $K_{\mathrm{D}}$ of fura-2/dextran varies between lots, there are no available data to compare with our estimate of $0.94 \mu \mathrm{M}$ (Fig. 1) (Haugland, 1995). We used these $K_{\mathrm{D}}$ values to convert ratio values to estimated $\left[\mathrm{Ca}^{2+}\right]_{\mathrm{i}}$ in all subsequent experiments.

Confocal microscopy. Optical sectioning through BTC-filled neurons under resting conditions was performed with a Noran Odyssey laser 


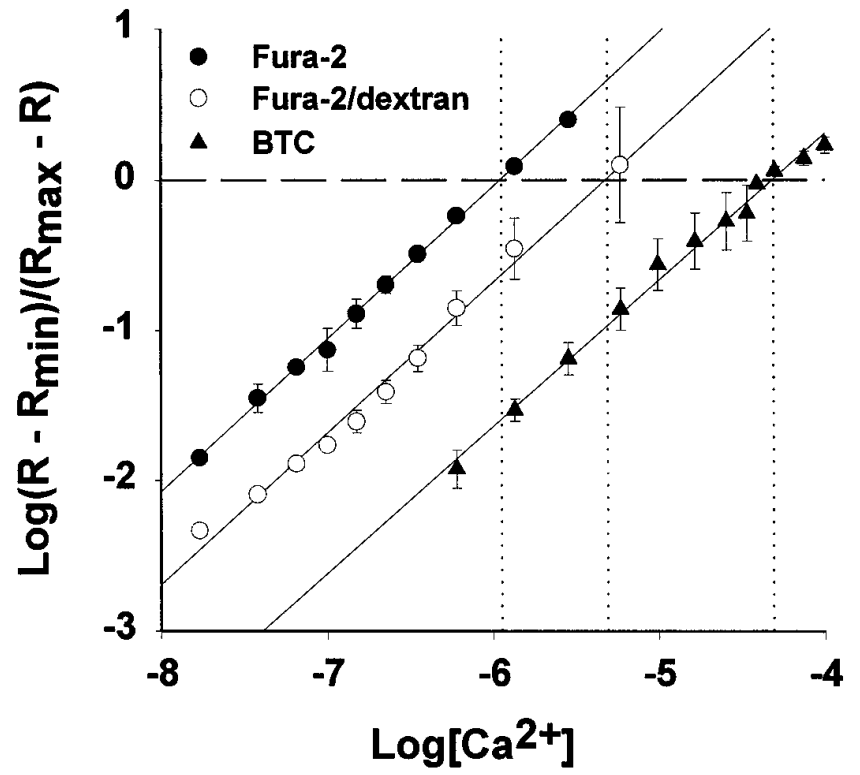

Figure 1. $\mathrm{Ca}^{2+}$ dissociation constants for fura-2, fura-2/dextran (MW 3000), and BTC. Spectrofluorimetric calibration curves were obtained for each indicator at $5.0 \mu \mathrm{M}$ in buffered solutions over an appropriate range of calcium concentrations. The data shown are averages of three calibration experiments performed for each indicator $($ mean \pm SD). To facilitate comparisons, the $x$-intercept and corresponding $\log \left[\mathrm{Ca}^{2+}\right]$ for each indicator are shown as dashed and dotted lines, respectively. Calculated $K_{\mathrm{D}}$ values are as follows: fura- $2(\bullet), 0.24 \pm 0.04 \mu \mathrm{M}$; fura-2/dextran $(\bigcirc)$, $0.94 \pm 0.25 \mu \mathrm{M} ; \mathrm{BTC}(\mathbf{\Delta}), 15.2 \pm 0.12 \mu \mathrm{M}$.

scanning confocal microscope (Noran Instruments, Middleton, WI) coupled to an inverted microscope (Nikon Diaphot), using a 60×, 1.2 NA water immersion objective lens (Nikon). BTC was illuminated with 488 $\mathrm{nm}$ excitation light. Frame-averaged ( 32 frames) images were collected at $0.5 \mu \mathrm{m}$ axial intervals with a confocal slit aperture of $25 \mu \mathrm{m}$. Images were saved to computer hard disk, and computer reconstruction was performed with the Metamorph image analysis system (Universal Imaging). A differential interference contrast (DIC) image of the neuron was collected by a transmitted light diode detector with DIC optics and 488 nm laser illumination.

Statistics. Comparisons between two groups used an unpaired Student's $t$ test (SigmaPlot, Jandel Scientific, SPSS, Chicago, IL).

\section{RESULTS}

When cortical cultures at 14-18 d in vitro were exposed to $300 \mu \mathrm{M}$ NMDA for $20 \mathrm{~min}$, there was widespread neuronal death by the next day, whereas the application of $450 \mu \mathrm{M}$ AMPA produced little neuronal loss (Fig. 2, inset). Despite this difference in toxicity, the $\left[\mathrm{Ca}^{2+}\right]_{\mathrm{i}}$ elevation, measured by conventional fura-2/AM ratiometric imaging, was similar in response to NMDA or AMPA, reaching 300-400 nм (Fig. 2, Table 1). These results are similar to previous reports from our own and other laboratories (Ogura et al., 1988; de Erausquin et al., 1990; Michaels and Rothman, 1990; Dubinsky and Rothman, 1991; Tymianski et al., 1993b; Lu et al., 1996).

One interpretation of these findings is that NMDA and AMPA elevate $\left[\mathrm{Ca}^{2+}\right]_{\mathrm{i}}$ to similar, submicromolar levels. Because the $\left[\mathrm{Ca}^{2+}\right]_{\mathrm{i}}$ values of $300-400 \mathrm{~nm}$ are well below the theoretical limit of fura-2/AM detection, $\sim 1-2 \mu \mathrm{M}$, we would not anticipate a problem of indicator saturation. However, previous reports on calcium permeability of NMDA receptors suggest that it is unlikely that calcium entry is similar after NMDA and AMPA receptor activation (Mayer and Westbrook, 1987; Goldberg and Choi, 1993; Hartley et al., 1993; Eimerl and Schramm, 1994).

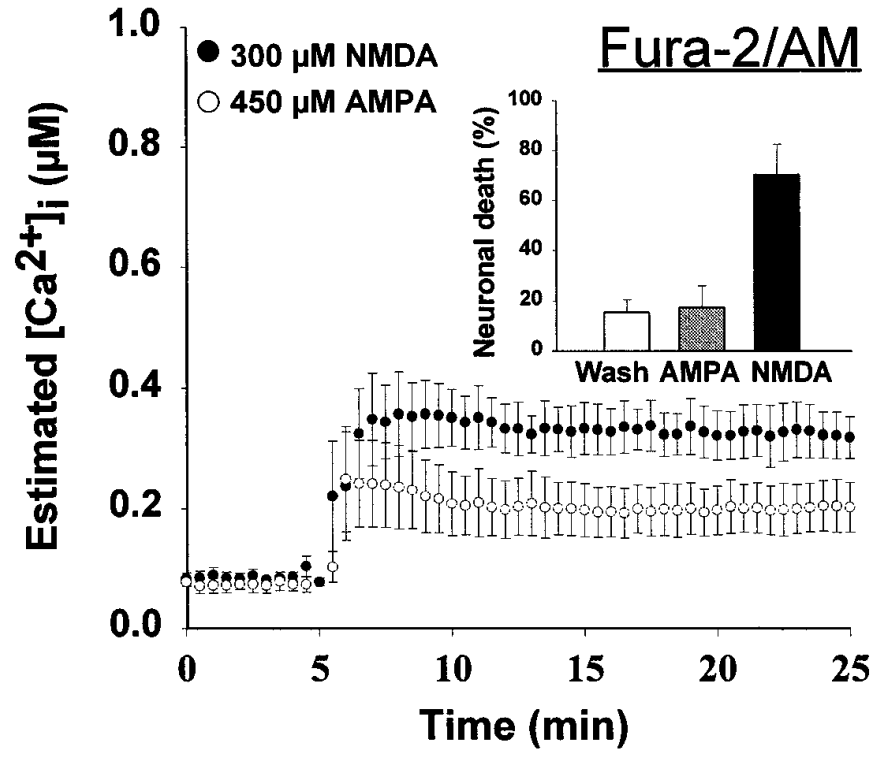

Figure 2. $\left[\mathrm{Ca}^{2+}\right]_{\mathrm{i}}$ levels measured using fura-2/AM do not differ during nontoxic AMPA and toxic NMDA exposures. Cultured cortical neurons were loaded by incubation with $6 \mu \mathrm{M}$ fura-2/AM, and neuronal $\left[\mathrm{Ca}^{2+}\right]$. was determined by fluorescence ratio imaging as described (see Materials and Methods) in neurons exposed to $300 \mu \mathrm{M}$ NMDA (with $10 \mu \mathrm{M}$ glycine) or $450 \mu \mathrm{M}$ AMPA (with $10 \mu \mathrm{M}$ MK-801 to prevent NMDA receptor activation). Values represent mean $( \pm \mathrm{SE})\left[\mathrm{Ca}^{2+}\right]_{i}$ derived from $15-20$ bath-loaded neurons in each of four to six dishes. Inset, Cultures were exposed for $20 \mathrm{~min}$ either to $300 \mu \mathrm{M}$ NMDA (with $10 \mu \mathrm{M}$ glycine) or to $450 \mu \mathrm{M}$ AMPA (with $10 \mu \mathrm{M}$ MK-801 to prevent NMDA receptor activation). After treatment, cells were washed with HBBSS with $10 \mu \mathrm{M} \mathrm{MK}$ 801 and returned to the incubator. Cell viability was assessed after 20-28 hr by trypan blue exclusion. Values represent mean ( \pm SD) percentage of nonviable neurons counted in 5-10 random fields in $10-15$ dishes.

Rather, we examined the possibility that the method of ratio imaging that used fura-2/AM might be under-reporting $\left[\mathrm{Ca}^{2+}\right]_{\mathrm{i}}$. There are several factors that might complicate the measurement of $\left[\mathrm{Ca}^{2+}\right]_{\mathrm{i}}$ with fura-2/AM. These include the high affinity of fura- 2 for calcium, incomplete hydrolysis of the acetoxymethyl ester, compartmentalization of fura-2/AM into organelles, and the contribution of fluorescence signal from underlying glial cells (Tsien, 1988; Roe et al., 1990; Kao, 1994). Unesterified molecules exhibit the spectral properties of unbound (i.e., calcium-free) fura- 2 and result in underestimation of $\left[\mathrm{Ca}^{2+}\right]_{\mathrm{i}}$. A significant indicator sequestration into calcium-insensitive compartments or the collection of fura-2 fluorescence from underlying glia also would affect the quantitation of $\left[\mathrm{Ca}^{2+}\right]_{i}$, because in these cases fluorescence is collected from dye molecules that are not located in the intraneuronal cytosolic compartment. Dye quenching with $\mathrm{Mn}^{2+}$ ions (2-5 mM $\mathrm{Mn}^{2+}$ with $50 \mu \mathrm{M}$ ionomycin) or cell membrane lysis with $10 \mu \mathrm{M}$ digitonin reduced fura-2 fluorescence to $\sim 10-20 \%$ of that of resting levels (data not shown), suggesting that a small proportion of the fura-2 was present in unesterified or compartmentalized forms, respectively. Signals from the glial monolayer may play a larger role in underestimating NMDAinduced $\left[\mathrm{Ca}^{2+}\right]_{i}$ elevation.

To avoid these problems, we repeated the NMDA and AMPA exposures after individual neurons had been loaded by transient patch electrode application with the potassium salt of fura- 2 (fura- $2 / \mathrm{K}^{+}$). Neuronal recovery after fura- $2 / \mathrm{K}^{+}$delivery via the patch pipette application was robust, as indicated by a healthy appearance under differential interference contrast imaging, uni- 


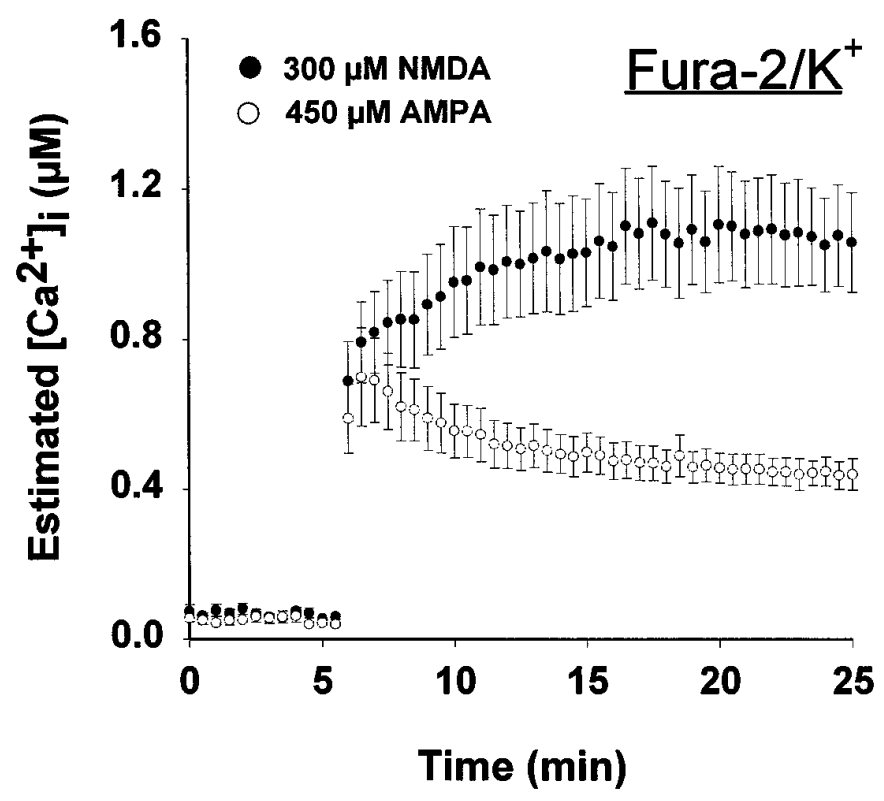

Figure 3. $\left[\mathrm{Ca}^{2+}\right]_{\mathrm{i}}$ measured by microinjected fura-2. Single neurons were filled with $500 \mu \mathrm{M}$ fura- 2 by transient patch micropipette application and exposed to AMPA or NMDA, as in Figure 2. Values represent mean $\pm \mathrm{SE}\left[\mathrm{Ca}^{2+}\right]_{\mathrm{i}}$ from four to six neurons.

form labeling of cytoplasm and processes, and typical low calcium at baseline. The $\left[\mathrm{Ca}^{2+}\right]_{\mathrm{i}}$ response in individual neurons loaded with fura- $2 / \mathrm{K}^{+}$and exposed to NMDA and AMPA was different from the $\left[\mathrm{Ca}^{2+}\right]_{i}$ response of neurons bath-loaded with fura-2/ AM. First, the peak $\left[\mathrm{Ca}^{2+}\right]_{\mathrm{i}}$ observed for both NMDA and AMPA was higher, ranging from 0.4 to $1 \mu \mathrm{M}$ (Fig. 3). Second, NMDA produced a prolonged $\left[\mathrm{Ca}^{2+}\right]_{\mathrm{i}}$ elevation that remained at $1 \mu \mathrm{M}$, whereas AMPA elicited a transient $\left[\mathrm{Ca}^{2+}\right]_{i}$ elevation, approaching $1 \mu \mathrm{M}$, followed by a rapid return to $\mathrm{nm}$ values. The peak $\left[\mathrm{Ca}^{2+}\right]_{\mathrm{i}}$ levels were not statistically different, although the integrated calcium load was significantly greater for NMDA (Table 2). Although this measure of $\left[\mathrm{Ca}^{2+}\right]_{i}$ correlated better with neuronal loss when fura- $2 / \mathrm{K}^{+}$was injected directly into the neurons, the absolute difference in $\left[\mathrm{Ca}^{2+}\right]_{\mathrm{i}}$ levels triggered by NMDA and AMPA was not very large (Table 2).

Although differences in calcium buffering (Sala and Hernandez-Cruz, 1990; Connor, 1993) potentially could contribute to differences in $\left[\mathrm{Ca}^{2+}\right]_{\mathrm{i}}$ measurements with fura-2/AM and injected fura-2, this does not seem likely to contribute to the present results. Despite the apparent difference in loading conditions (30 min incubation with $6 \mu \mathrm{M}$ fura-2/AM vs $60 \mathrm{sec}$ diffusion with $500 \mu \mathrm{M}$ fura- $\left.2 / \mathrm{K}^{+}\right)$, the fluorescence intensities of injected and bath-loaded cells were similar, indicating that the intracellular dye concentrations and, consequently, distortions because of calcium buffering were comparable. Comparison of the fluorescence intensity of fura- 2 injected cells and fura- 2 in $20 \mu \mathrm{m}$ microslides suggested that the actual dye concentration in injected cells was on the order of $25 \mu \mathrm{M}$, less than the amount predicted to cause significant buffering effect (Sala and Hernandez-Cruz, 1990).

We were concerned that the high affinity of fura- 2 for calcium $\left(K_{\mathrm{D}} \sim 0.22 \mu \mathrm{M}\right)$ might preclude an accurate estimate of $\left[\mathrm{Ca}^{2+}\right]_{\mathrm{i}}$ exceeding $1 \mu \mathrm{M}$. Therefore, we repeated the NMDA and AMPA exposures in individual neurons loaded with BTC, which has a $K_{\mathrm{D}}$ for calcium of $\sim 15 \mu \mathrm{M}$ (see Materials and Methods). In contrast to either form of fura-2, BTC revealed a large difference in the

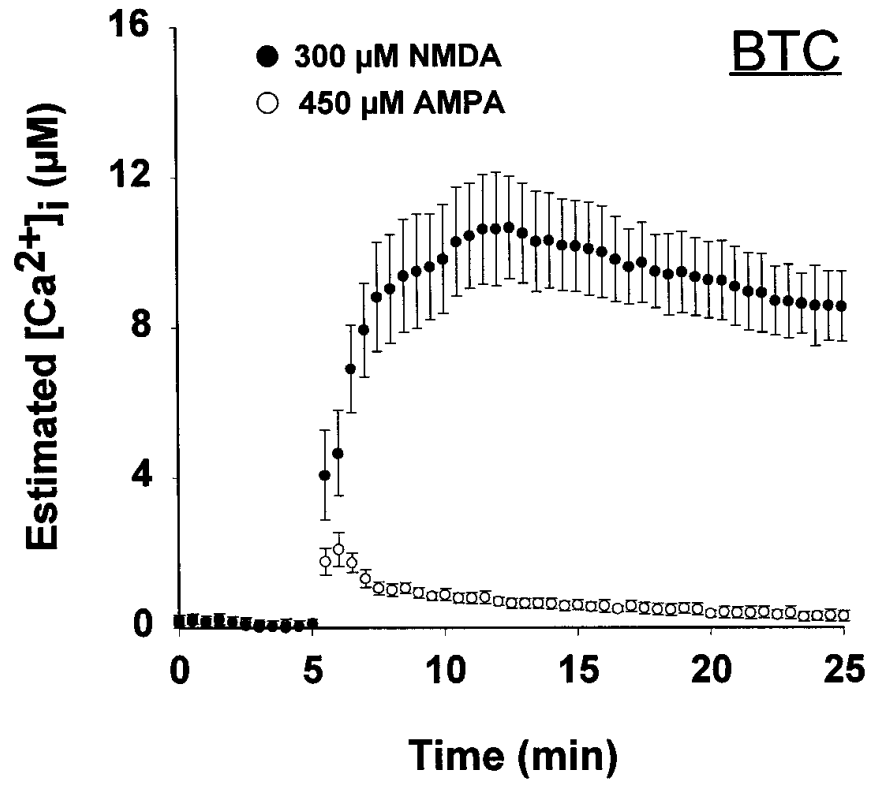

Figure 4. $\left[\mathrm{Ca}^{2+}\right]_{\mathrm{i}}$ measured by microinjected BTC. Single neurons were filled with the low-affinity calcium indicator BTC $\left(500 \mu \mathrm{M} ; K_{\mathrm{D}}=15 \mu \mathrm{M}\right)$ and exposed to AMPA or NMDA, as in Figure 2. Values represent mean $\pm \mathrm{SE}\left[\mathrm{Ca}^{2+}\right]_{\mathrm{i}}$ from four to six neurons. BTC reveals large differences between NMDA- and AMPA-induced $\left[\mathrm{Ca}^{2+}\right]_{i}$ elevation.

$\left[\mathrm{Ca}^{2+}\right]_{\mathrm{i}}$ response to NMDA and AMPA treatment (Fig. 4). After NMDA exposure, BTC reported a rapid increase in $\left[\mathrm{Ca}^{2+}\right]_{i}$ to 5-10 $\mu \mathrm{M}$, whereas AMPA exposure produced a transient elevation not exceeding $3 \mu \mathrm{M}$, which decreased to $<0.5 \mu \mathrm{M}$ within $5 \mathrm{~min}$ (Fig. 4). Toxic NMDA receptor activation provoked peak $\left[\mathrm{Ca}^{2+}\right]_{i}$ at least 2.5-fold greater than that of AMPA receptor activation (Table 1). This difference was magnified when $\left[\mathrm{Ca}^{2+}\right]_{i}$ was integrated for the $20 \mathrm{~min}$ exposure period (Table 2). The integrated response to AMPA application was similar with fura- $2 / \mathrm{K}^{+}$and BTC measurement, 9.1 versus $11.3 \mu \mathrm{M} / \mathrm{min}$, respectively (not significant; Table 2). We used confocal microscopy to ensure that the BTC results did not reflect localized distribution of the novel indicator. Confocal optical sections through BTC-filled neurons revealed a relatively homogeneous distribution of BTC fluorescence, with minimal indicator compartmentalization (Fig. 5).

We also have compared $\left[\mathrm{Ca}^{2+}\right]_{\mathrm{i}}$ responses to NMDA and AMPA with two other low-affinity indicators, mag-fura-2 and Calcium Green-5N. The changes in mag-fura- 2 ratio values or Calcium Green-5N intensity values were much greater after exposure to NMDA than AMPA (data not shown), consistent with the BTC result. We did not use these indicators extensively, because quantification of $\left[\mathrm{Ca}^{2+}\right]_{\mathrm{i}}$ can be problematic with both. Intracellular ionized magnesium contaminates the mag-fura-2 signal, and calibration of single excitation indicators like Calcium Green-5N is difficult (Brocard et al., 1993; Rajdev and Reynolds, 1993; Stout et al., 1996). BTC ratio values are not affected significantly by alterations in $\left[\mathrm{Mg}^{2+}\right]$ in the $0-10 \mathrm{~mm}$ range (Iatridou et al., 1994; Hyrc et al., 1997).

To determine whether the differential reporting of $\left[\mathrm{Ca}^{2+}\right]_{i}$ by fura-2 and BTC was the result of differences in intracellular distribution, we filled neurons with fura- 2 coupled to a dextran (3000 MW; fura-2/dextran), which restricts the distribution of the indicator to the cytoplasm (Kao, 1994). Fura-2/dextran had an intermediate affinity for calcium, $K_{\mathrm{D}} 0.9 \mu \mathrm{M}$ (see Fig. 1). In 


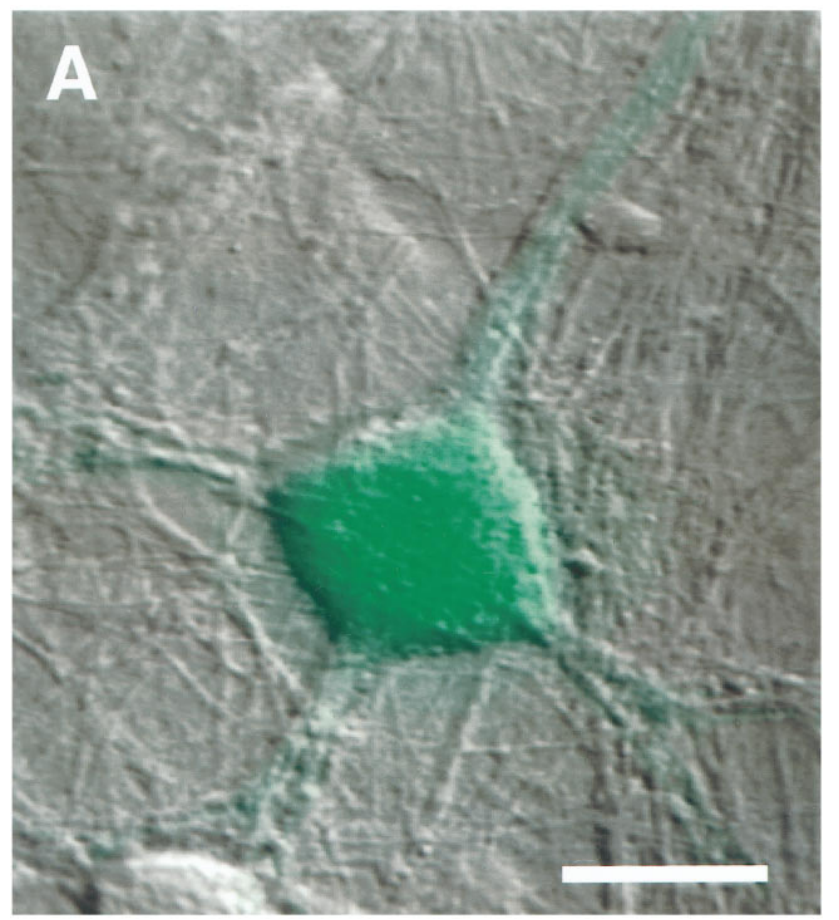

B
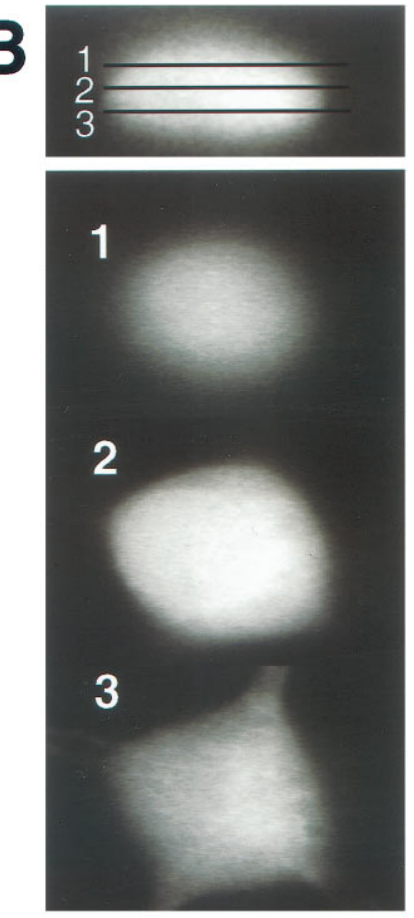

Figure 5. Cellular distribution of BTC in an individual dye-filled cortical neuron. Optical sections were taken at 0.5 $\mu \mathrm{m}$ intervals, using a laser scanning confocal microscope. $A$, A through-focus confocal image of BTC (green) overlayed on the Nomarski image (scale bar, $15 \mu \mathrm{m}) . B$, The BTC fluorescence data ( $x z$ cross section) are shown in the upper right, with the indicated $x y$ planes shown below (scale for these images is $12 \mu \mathrm{m}$ ). BTC appears uniformly distributed throughout the neuronal cytoplasm. response to NMDA or AMPA exposure, the difference in ratio values reported by fura-2/dextran was substantially larger than that of fura- $2 / \mathrm{K}^{+}$(Fig. 6), and the $\left[\mathrm{Ca}^{2+}\right]_{\mathrm{i}}$ levels after AMPA exposure were similar to the levels reported by BTC. The peak $\left[\mathrm{Ca}^{2+}\right]_{\mathrm{i}}$ reported by fura-2/dextran was significantly higher after NMDA exposure, reaching levels of $7 \mu \mathrm{M}$, as compared with 2.5 $\mu \mathrm{M}$ with AMPA treatment (Table 1); this difference was substantial at all time points (Fig. 6). Like BTC, fura-2/dextran reported a highly significant difference in integrated $\left[\mathrm{Ca}^{2+}\right]_{\mathrm{i}}$ during NMDA and AMPA exposure (Table 2).

We considered the possibility that fura-2 and BTC might provide distinctly different results only under conditions of lethal NMDA receptor activation. Therefore, we examined $\left[\mathrm{Ca}^{2+}\right]_{i}$ during brief, nontoxic exposures to different excitatory amino acids or elevated extracellular potassium. Two minute exposures to $50 \mathrm{~mm} \mathrm{KCl,} 450 \mu \mathrm{M}$ kainate, $450 \mu \mathrm{M}$ AMPA, $300 \mu \mathrm{M}$ glutamate, or $300 \mu \mathrm{M}$ NMDA produced little neuronal death after $1 \mathrm{~d}$ (data not shown). With fura- $2 / \mathrm{K}^{+}$, estimated $\left[\mathrm{Ca}^{2+}\right]_{\mathrm{i}}$ reached $\sim 0.5-1.0 \mu \mathrm{M}$ in the second minute of exposure in all conditions (Fig. $7 A$ ) and did not differ significantly among conditions (Fig. $7 C$ ). With BTC as the calcium indicator, $\mathrm{KCl}$, AMPA, or kainate transiently elevated $\left[\mathrm{Ca}^{2+}\right]_{\mathrm{i}}$ to $2 \mu \mathrm{M}$, with a return to nanomolar levels within the 2 min (Fig. 7B). Glutamate and NMDA provoked substantially higher, sustained $\left[\mathrm{Ca}^{2+}\right]_{\mathrm{i}}$ elevations to $8 \mu \mathrm{M}$ (Fig. 7B,C).

It is well recognized that fluorescent ion indicators provide little information under saturating conditions in which virtually all indicator molecules are already bound (in the case of fura-2, $\left[\mathrm{Ca}^{2+}\right]_{\mathrm{i}}$ above $\left.1-2 \mu \mathrm{M}\right)$. However, that situation did not seem to apply in these experiments. When we applied the calcium ionophore ionomycin $(50 \mu \mathrm{M})$ to fura- $2 / \mathrm{K}^{+}$-injected neurons, $\left[\mathrm{Ca}^{2+}\right]_{\mathrm{i}}$ rose to $2.5 \mu \mathrm{M}$, a concentration much higher than that produced by NMDA or glutamate (Fig. $7 A$ ). These results suggest that fura-2 was not saturated fully during NMDA- or glutamateinduced calcium influx.

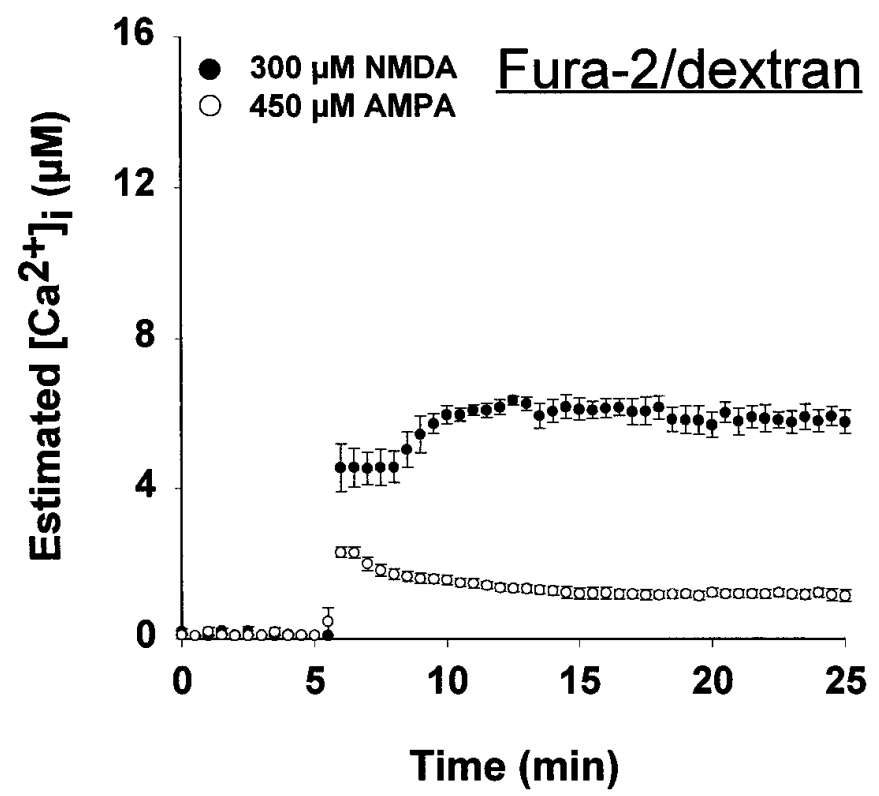

Figure 6. $\left[\mathrm{Ca}^{2+}\right]_{\mathrm{i}}$ levels measured with fura-2/dextran. Neurons were filled with fura- 2 conjugated to $3000 \mathrm{MW}$ dextran $\left(500 \mu \mathrm{M} ; K_{\mathrm{D}}=0.94\right.$ $\mu \mathrm{M})$ and exposed to NMDA or AMPA as in Figure 2. Values represent mean $\pm \mathrm{SE}\left[\mathrm{Ca}^{2+}\right]_{\mathrm{i}}$ from four to six neurons.

\section{DISCUSSION}

The role of $\left[\mathrm{Ca}^{2+}\right]_{\mathrm{i}}$ in excitotoxic neuronal death has been a topic of considerable debate, primarily because of conflicting evidence obtained by different methods of $\left[\mathrm{Ca}^{2+}\right]_{i}$ measurement. A lack of correlation between the magnitude of early $\left[\mathrm{Ca}^{2+}\right]_{i}$ elevation and subsequent excitotoxic death was noted by us originally and confirmed by others (Michaels and Rothman, 1990; Dubinsky and Rothman, 1991; Tymianski et al., 1993a,b; Lu et al., 1996). We replicated our earlier observations in this paper: maximum 

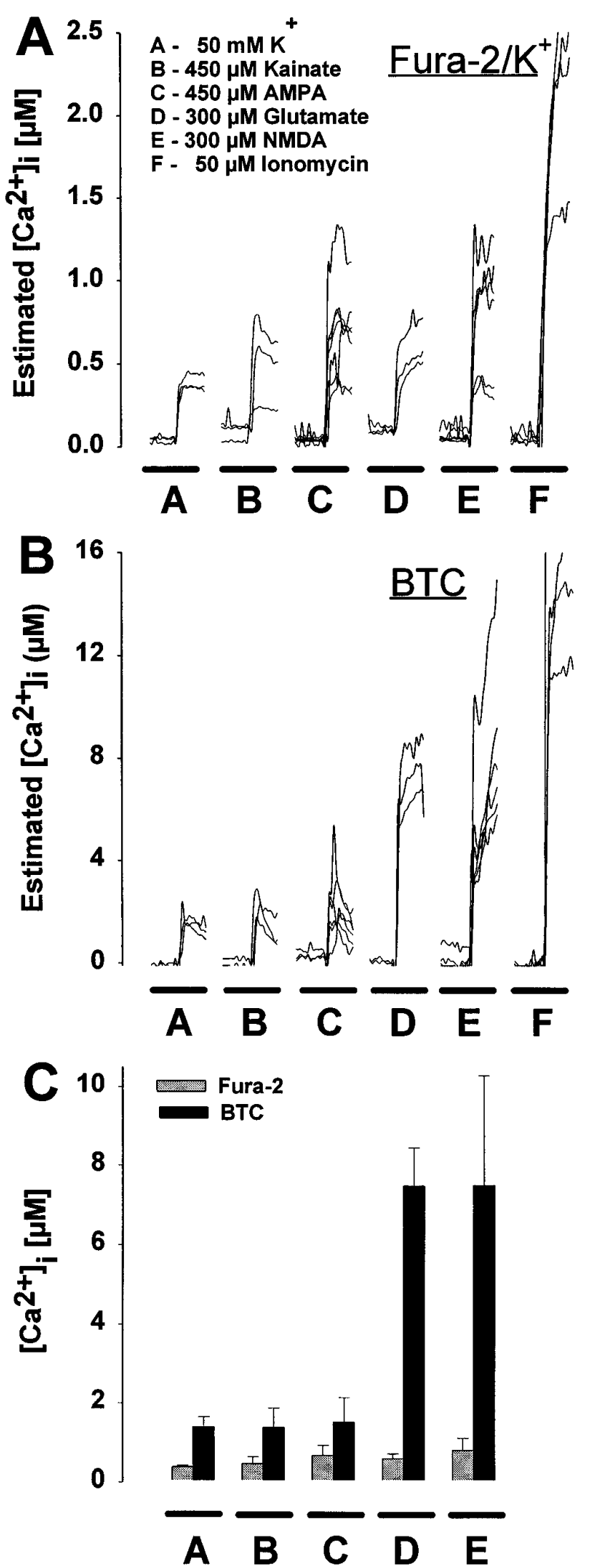

Figure 7. Fura-2 and BTC report markedly different $\left[\mathrm{Ca}^{2+}\right]_{\mathrm{i}}$ levels even during sublethal exposure conditions. Neurons were exposed for 2 min to $50 \mathrm{~mm} \mathrm{KCl}, 450 \mu \mathrm{M}$ kainate or AMPA, $300 \mu \mathrm{M}$ glutamate or NMDA, or $50 \mu \mathrm{M}$ ionomycin after microinjection with either fura-2 $(A)$ or BTC $(B)$.
Table 1. Maximal $\left[\mathrm{Ca}^{2+}\right]_{\mathrm{i}}$ (in $\left.\mu \mathrm{M}\right)$ observed during 20 min drug treatment

\begin{tabular}{llcl} 
& $450 \mu \mathrm{M}$ AMPA & $300 \mu \mathrm{M}$ NMDA & $p^{a}$ \\
\hline Fura-2/AM & $0.3 \pm 0.2^{b}(4)^{c}$ & $0.4 \pm 0.1(3)$ & $p>0.26$ \\
Fura-2/K & $0.8 \pm 0.3(7)$ & $1.2 \pm 0.5(11)$ & $p=0.065$ \\
BTC & $2.8 \pm 1.4(6)$ & $11.4 \pm 3.9(6)$ & $p<0.0005$ \\
Fura-2/dextran & $2.5 \pm 0.2(4)$ & $6.8 \pm 0.5(4)$ & $p<0.005$
\end{tabular}

${ }^{a}$ Student's $t$ test; ${ }^{b}$ mean $\pm \mathrm{SD} ;{ }^{c}$ number of dishes.

Table 2. Total calcium load (in $\mu \mathrm{M} \bullet \min$ ) calculated as the integral of calcium during 20 min drug treatment

\begin{tabular}{lccl} 
& $450 \mu \mathrm{M}$ AMPA & $300 \mu \mathrm{M}$ NMDA & $p^{a}$ \\
\hline Fura-2/AM & $2.6 \pm 1.6^{b}(4)^{c}$ & $5.0 \pm 1.5(3)$ & $p>0.12$ \\
Fura-2/K & $9.1 \pm 2.7(7)$ & $18.5 \pm 8.8(11)$ & $p=0.015$ \\
BTC & $11.3 \pm 4.1(6)$ & $180 \pm 48(6)$ & $p<0.0001$ \\
Fura-2/dextran & $23.5 \pm 4.2(4)$ & $108 \pm 11.5(4)$ & $p<0.0001$ \\
\hline
\end{tabular}

${ }^{a}$ Student's $t$ test; ${ }^{b}$ mean $\pm \mathrm{SD} ;{ }^{c}$ number of dishes.

$\left[\mathrm{Ca}^{2+}\right]_{\mathrm{i}}$ (measured with fura-2/AM) was no higher during an NMDA exposure that was ultimately lethal than during a nonlethal exposure to AMPA. These results stand in sharp contrast to calcium flux experiments that report substantially greater ${ }^{45} \mathrm{Ca}^{2+}$ uptake during NMDA receptor activation (Marcoux et al., 1988; Hartley et al., 1993; Eimerl and Schramm, 1994; Lu et al., 1996). However, glutamate receptor activation can lead to marked elevation of $\left[\mathrm{Ca}^{2+}\right]_{\mathrm{i}}$ (MacDermott et al., 1986; Rajdev and Reynolds, 1993), and biophysical investigations indicate much higher calcium permeability of NMDA receptors (MacDermott et al., 1986; Mayer and Westbrook, 1987; McBain and Mayer, 1994).

In view of this apparent discrepancy, we tested the hypothesis that the choice of indicator is critically important in obtaining an accurate estimate of $\left[\mathrm{Ca}^{2+}\right]_{\mathrm{i}}$. When we switched from fura-2 to lower-affinity indicators, the correlation between $\left[\mathrm{Ca}^{2+}\right]_{\mathrm{i}}$ rise and neuronal death markedly improved. We found sustained micromolar levels of $\left[\mathrm{Ca}^{2+}\right]_{\mathrm{i}}$ during toxic NMDA receptor activation, whereas nonlethal perturbations (e.g., $\mathrm{K}^{+}$depolarization, AMPA, or kainate receptor activation), resulted in transient $\left[\mathrm{Ca}^{2+}\right]_{\mathrm{i}}$ elevations that rapidly returned to nanomolar levels.

There are several reasons why our older $\left[\mathrm{Ca}^{2+}\right]_{\mathrm{i}}$ determinations with fura- 2 failed to anticipate correctly the outcome of excitotoxic paradigms. The usual method of indicator loading by bath application of the acetoxymethyl ester (fura-2/AM) contributed to underestimation of the differences between AMPA- and NMDA-induced $\left[\mathrm{Ca}^{2+}\right]_{\mathrm{i}}$ elevation; this is apparent in the different results obtained by using microinjected free indicator (fura$2 / \mathrm{K}^{+}$) under identical exposure conditions (compare Figs. 2 and 3 ). By allowing active indicator to diffuse directly into neurons through patch pipettes, we eliminated several potential problems associated with the use of the acetoxymethyl ester form of fura- 2

Each trace represents estimated $\left[\mathrm{Ca}^{2+}\right]_{\mathrm{i}}$ from a single neuron. $C$, Mean \pm SD $\left[\mathrm{Ca}^{2+}\right]_{\mathrm{i}}$ elevation during the second minute of drug application in $A$ or $B$. With the use of fura-2, measured $\left[\mathrm{Ca}^{2+}\right]_{\mathrm{i}}$ increased to a similar level for each treatment except ionomycin $(A, C)$. In contrast, measurements using BTC revealed a significant difference in $\left[\mathrm{Ca}^{2+}\right]_{\mathrm{i}}$ among cells treated with $\mathrm{KCl}$, kainate or AMPA, and cells exposed to NMDA or glutamate $(B, C)$. In fura-2-filled neurons, ionomycin application elevated $\left[\mathrm{Ca}^{2+}\right]_{\mathrm{i}}$ to a significantly greater extent than other drug treatments $(A)$, suggesting that fura- 2 was not saturated in these experiments. 
(Tsien, 1988; Roe et al., 1990; Kao, 1994), including incomplete deesterification, indicator compartmentalization, and contributing stray light from the underlying glial layer. Each of these problems results in underestimation of peak $\left[\mathrm{Ca}^{2+}\right]_{i}$ because of fluorescence signals from fura- 2 molecules that are insensitive to calcium (unesterified fura-2/AM) or that are not exposed to neuron-specific changes in calcium (fura-2 in astrocytes or in noncytosolic intracellular compartments).

Our results suggest that the most important limitations of fura- 2 in previous experiments stem from its high calcium affinity $\left(K_{\mathrm{D}} \sim 0.22 \mu \mathrm{M}\right)$. At micromolar calcium concentrations, almost all of fura- 2 is bound, and therefore it cannot distinguish accurately the differences in $\left[\mathrm{Ca}^{2+}\right]_{\mathrm{i}}$ (Tsien, 1988). Our observations using two low-affinity indicators, BTC and fura-2/dextran, suggest that AMPA-induced $\left[\mathrm{Ca}^{2+}\right]_{i}$ elevation is measured accurately by fura-2 but that NMDA-induced $\left[\mathrm{Ca}^{2+}\right]_{\mathrm{i}}$ elevation $(7-12 \mu \mathrm{M}$, Table 1) is considerably higher than this range. We believe these results reflect a real difference in cytosolic calcium levels rather than an artifact caused by the indicator or imaging properties. For example, because in vitro calibration methods cannot reproduce the exact intracellular milieu, it is possible that inaccurate determination of indicator $K_{\mathrm{D}}$ artificially might elevate the estimated $\left[\mathrm{Ca}^{2+}\right]_{\mathrm{i}}$. However, these considerations are not likely to account for the marked discrepancy between NMDA- and AMPAinduced $\left[\mathrm{Ca}^{2+}\right]_{\mathrm{i}}$ elevation, which should be affected to the same extent by any errors in calibration. Independent of the calculated $\left[\mathrm{Ca}^{2+}\right]_{\mathrm{i}}$, the ratio changes with BTC and fura-2/dextran were substantially larger during NMDA than AMPA exposure.

We specifically considered effects of magnesium and $\mathrm{pH}$, because these are known to alter the properties of many calcium indicators. The calcium affinity and excitation ratios of BTC are not affected substantially by $\mathrm{Mg}^{2+}$ in the millimolar range (Iatridou et al., 1994; Hyrc et al., 1997). We avoided using two other low-affinity ratiometric $\mathrm{Ca}^{2+}$ indicators, mag-fura-2 and magfura-5, because of their higher sensitivity to physiological levels of magnesium (Brocard et al., 1993; Stout et al., 1996). Although many calcium indicators are also sensitive to $\mathrm{pH}$ and glutamate receptor activation lowers intracellular $\mathrm{pH}$ (Hartley and Dubinsky, 1993), alterations in $\mathrm{pH}_{\mathrm{i}}$ did not account for the large $\left[\mathrm{Ca}^{2+}\right]_{\mathrm{i}}$ elevation observed with BTC during NMDA, but not AMPA, application. In preliminary experiments with the fluorescent $\mathrm{pH}$ indicator BCECF, NMDA and AMPA exposures reduced neuronal $\mathrm{pH}_{\mathrm{i}}$ to a similar extent, $\mathrm{pH} \sim 6.7-6.8$. Further, spectrofluorimetric measurements with $\mathrm{BTC}$ indicate that acidic $\mathrm{pH}$ levels would lead to moderate underestimation of $\left[\mathrm{Ca}^{2+}\right]_{i}$ and that actual calcium concentrations may be $30-40 \%$ higher than levels estimated by assuming pH 7.2 (Hyrc et al., 1997).

Microinjected BTC has several desirable properties for future studies requiring a low-affinity calcium indicator: it has a high selectivity for calcium over magnesium and other divalent cations, it provides ratiometric calcium determination, and it allows visible wavelength excitation, avoiding the requirement for special UVtransparent optics. Fura-2/dextran also demonstrates promising features as a microinjectable indicator with cytosolic distribution and intermediate calcium affinity. In preliminary experiments, bath application of BTC by its acetoxymethyl ester (BTC/AM) provided results qualitatively similar to those obtained with the use of injected BTC. The quantitative analysis of these results is, however, subject to the same restrictions that apply to fura-2/AM and is likely to yield underestimated $\left[\mathrm{Ca}^{2+}\right]_{\mathrm{i}}$ (Hyrc et al., 1997).

Although affinity differences among indicators partially explain the inability of earlier research with fura- 2 and indo- 1 to correlate reliably the $\left[\mathrm{Ca}^{2+}\right]_{\mathrm{i}}$ and outcome in neurotoxicity experiments, there are other factors that complicate this analysis. Our initial observations with fura- 2 suggested that calcium concentrations after NMDA receptor activation did not reach micromolar levels expected to saturate this indicator (e.g., Fig. 7A). Indeed, ionomycin application doubled the $\left[\mathrm{Ca}^{2+}\right]_{\mathrm{i}}$ levels reported by fura$2 / \mathrm{K}^{+}$(Fig. $7 A$ ). Therefore, we were surprised to find much higher $\left[\mathrm{Ca}^{2+}\right]_{\mathrm{i}}$ reported with BTC and fura-2/dextran during NMDA exposure, concentrations that should be more than sufficient to saturate fura-2.

There are at least two possible reasons for this apparent paradox. First, discrepant results might be caused by differences in indicator distribution, such that fura-2 is sequestered in calciuminsensitive compartments or BTC in high calcium areas. However, digitonin $(10 \mu \mathrm{M})$ treatment led to the loss of $85-95 \%$ of fluorescence of microinjected fura- 2 and BTC, suggesting that both indicators were confined primarily in the cytoplasm. Confocal imaging of the distribution of BTC (Fig. 5) and of fura-2 (S. D. Handran and R. S. Hotchkiss, unpublished results) confirmed that neither indicator was compartmentalized substantially. Furthermore, similar results were obtained with fura-2/dextran, which is predicted to have a uniform cytosolic distribution. Second, the results may be explained by a spatially heterogeneous calcium distribution during NMDA receptor activation. Activation of calcium-permeable membrane channels elevates $\left[\mathrm{Ca}^{2+}\right]_{i}$ in microdomains, with $\left[\mathrm{Ca}^{2+}\right]_{\mathrm{i}}$ reaching 50-100 $\mu \mathrm{M}$ (Smith and Augustine, 1988; Augustine and Neher, 1992; Llinás et al., 1992a,b; Neher and Augustine, 1992; Petrozzino et al., 1995). All high-affinity indicator molecules located within such microdomains will be saturated rapidly, leaving a portion of the indicator in other areas unbound. The fura- 2 response to ionomycin, which forms a calcium/proton shuttle (Nicholls and Ferguson, 1992), could result in a higher reported $\left[\mathrm{Ca}^{2+}\right]_{\mathrm{i}}$ if ionomycin globally elevates $\left[\mathrm{Ca}^{2+}\right]_{\mathrm{i}}$. Thus, fura-2 fails to measure $\left[\mathrm{Ca}^{2+}\right]_{\mathrm{i}}$ accurately when high calcium microdomains are present because a large portion of the indicator pool is saturated. Although this may occur with any calcium indicator, a low-affinity indicator such as BTC is less likely to be saturated under the same conditions (Petrozzino et al., 1995; Ito et al., 1997). Under our imaging conditions we were unable to visualize such microdomains; a histogram of the distribution of pixel ratio values within the cell body during peak NMDA receptor activation did not support the presence of two populations of $\left[\mathrm{Ca}^{2+}\right]_{i}$ (data not shown). Therefore, any calcium heterogeneity occurred below the spatial and temporal resolution of our imaging apparatus.

These results have immediate consequences for a large number of experiments that use fura- 2 and other high-affinity calcium indicators. Many such experiments may be accurate qualitatively but are unlikely to provide a correct determination of $\left[\mathrm{Ca}^{2+}\right]_{i}$ beyond the normal physiological range, $\sim 50-500 \mathrm{~nm}$, if substantial calcium microdomains are present. Importantly, our results indicate that widely used high-affinity indicators, such as fura-2, may selectively underestimate $\left[\mathrm{Ca}^{2+}\right]_{\mathrm{i}}$, depending on the route of calcium entry. This can occur under lethal or nonlethal conditions and at calcium levels that appear to be well within the range of accurate detection.

One clear message from the present experiments is that $\left[\mathrm{Ca}^{2+}\right]_{\mathrm{i}}$ can rise to concentrations reaching $5-10 \mu \mathrm{M}$ during excitotoxic exposures. Our results further establish that $\left[\mathrm{Ca}^{2+}\right]_{i}$ measurement with low-affinity indicators distinguishes the vulnerability of neurons in excitotoxicity paradigms. This result has implications for investigators attempting to unravel the intracel- 
lular pathways that play an early role in triggering or propagating the signals that ultimately are responsible for neuronal death. We now may appreciate the possibility that catabolic enzymes and modulators with relatively low affinity for calcium are activated in these cascades.

\section{REFERENCES}

Augustine GJ, Neher E (1992) Neuronal $\mathrm{Ca}^{2+}$ signaling takes the local route. Curr Opin Neurobiol 2:302-307.

Brocard JB, Rajdev S, Reynolds IJ (1993) Glutamate-induced increases in intracellular free $\mathrm{Mg}^{2+}$ in cultured cortical neurons. Neuron 11:751-757.

Canzoniero LMT, Sensi SL, Choi DW (1996) Recovery from NMDAinduced intracellular acidification is delayed and dependent on extracellular bicarbonate. Am J Physiol 39:C593-C599.

Choi DW (1987) Ionic dependence of glutamate neurotoxicity in cortical cell culture. J Neurosci 7:369-379.

Choi DW (1992) Excitotoxic cell death. J Neurobiol 23:1261-1276.

Choi DW, Maulucci-Gedde MA, Kriegstein AR (1987) Glutamate neurotoxicity in cortical cell culture. J Neurosci 7:357-368.

Choi DW, Koh J, Peters S (1988) Pharmacology of glutamate neurotoxicity in cortical cell culture: attenuation by NMDA antagonists. J Neurosci 8:185-196.

Connor JA (1993) Intracellular calcium mobilization by inositol 1,4,5trisphosphate: intracellular movements and compartmentalization. Cell Calcium 14:185-200.

Connor JA, Tseng HY, Hockberger PE (1987) Depolarization- and transmitter-induced changes in intracellular $\mathrm{Ca}^{2+}$ of rat cerebellar granule cells in explant cultures. J Neurosci 7:1384-1400.

Connor JA, Wadman WJ, Hockberger PE, Wong RK (1988) Sustained dendritic gradients of $\mathrm{Ca}^{2+}$ induced by excitatory amino acids in CA1 hippocampal neurons. Science 240:649-653.

de Erausquin GA, Manev H, Guidotti A, Costa E, Brooker G (1990) Gangliosides normalize distorted single-cell intracellular free $\mathrm{Ca}^{2+}$ dynamics after toxic doses of glutamate in cerebellar granule cells. Proc Natl Acad Sci USA 87:8017-8021.

Dubinsky JM (1993a) Examination of the role of calcium in neuronal death. Ann NY Acad Sci 679:34-42.

Dubinsky JM (1993b) Intracellular calcium levels during the period of delayed excitotoxicity. J Neurosci 13:623-631.

Dubinsky JM, Rothman SM (1991) Intracellular calcium concentrations during "chemical hypoxia" and excitotoxic neuronal injury. J Neurosci 11:2545-2551.

Eimerl S, Schramm M (1994) The quantity of calcium that appears to induce neuronal death. J Neurochem 62:1223-1226.

Goldberg MP, Choi DW (1993) Combined oxygen and glucose deprivation in cortical cell culture: calcium-dependent and calciumindependent mechanisms of neuronal injury. $J$ Neurosci 13:3510-3524.

Grynkiewicz G, Poenie M, Tsien RY (1985) A new generation of $\mathrm{Ca}^{2+}$ indicators with greatly improved fluorescence properties. J Biol Chem 260:3440-3450.

Hamill OP, Marty A, Neher E, Sakmann B, Sigworth FJ (1981) Improved patch-clamp techniques for high-resolution current recording from cells and cell-free membrane patches. Pflügers Arch 391:85-100.

Hartley DM, Choi DW (1989) Delayed rescue of $N$-methyl-D-aspartate receptor-mediated neuronal injury in cortical culture. J Pharmacol Exp Ther 250:752-758.

Hartley DM, Kurth MC, Bjerkness L, Weiss JH, Choi DW (1993) Glutamate receptor-induced ${ }^{45} \mathrm{Ca}^{2+}$ accumulation in cortical cell culture correlates with subsequent neuronal degeneration. J Neurosci 13:1993-2000.

Hartley Z, Dubinsky JM (1993) Changes in intracellular pH associated with glutamate excitotoxicity. J Neurosci 13:4690-4699.

Haugland RP (1995) Molecular Probes handbook of fluorescent probes and research chemicals. Portland, OR: Molecular Probes.

Hyrc KH, Handran SD, Rothman SM, Goldberg MP (1996) Lowaffinity calcium indicators distinguish lethal calcium entry during glutamate receptor activation in cultured neurons. Soc Neurosci Abstr 22:798.

Hyrc KH, Bownik JM, Handran SD, Rothman SM, Goldberg MP (1997) Properties of BTC, a novel low-affinity calcium indicator. Soc Neurosci Abstr, in press.
Iatridou H, Foukaraki E, Kuhn MA, Marcus EM, Haugland RP, Katerinopoulos HE (1994) The development of a new family of intracellular calcium probes. Cell Calcium 15:190-198.

Ito K, Miyashita Y, Kasai H (1997) Micromolar and submicromolar $\mathrm{Ca}^{2+}$ spikes regulating distinct cellular functions in pancreatic acinar cells. EMBO J 16:242-251.

Kao JP (1994) Practical aspects of measuring $\left[\mathrm{Ca}^{2+}\right]$ with fluorescent indicators. Methods Cell Biol 40:155-181.

Koh J, Goldberg MP, Hartley DM, Choi DW (1990) Non-NMDA receptor-mediated neurotoxicity in cortical culture. J Neurosci 10:693-705.

Konishi M, Watanabe M (1995) Resting cytoplasmic free $\mathrm{Ca}^{2+}$ concentration in frog skeletal muscle measured with fura- 2 conjugated to high molecular weight dextran. J Gen Physiol 106:1123-1150.

Limbrick Jr DD, Churn SB, Sombati S, DeLorenzo RJ (1995) Inability to restore resting intracellular calcium levels as an early indicator of delayed neuronal cell death. Brain Res 690:145-156.

Llinás R, Sugimori M, Silver RB (1992a) Microdomains of high calcium concentration in presynaptic terminal. Science 256:677-679.

Llinás R, Sugimori M, Silver RB (1992b) Presynaptic calcium concentration microdomains and transmitter release. J Physiol (Paris) 86:135-138.

Lu YM, Yin HZ, Chiang J, Weiss JH (1996) $\mathrm{Ca}^{2+}$-permeable AMPA/ kainate and NMDA channels: high rate of $\mathrm{Ca}^{2+}$ influx underlies potent induction of injury. J Neurosci 16:5457-5465.

MacDermott AB, Mayer ML, Westbrook GL, Smith SJ, Barker JL (1986) NMDA receptor activation increases cytoplasmic calcium concentration in cultured spinal cord neurones. Nature 321:519-522.

Marcoux FW, Goodrich JE, Probert AWJ, Dominick MA (1988) Ketamine prevents glutamate-induced calcium influx and ischemic nerve cell injury. In: Sigma and phencylidine-like compounds as molecular probes in biology (Domino EF, Kamenka JM, eds), pp 735-746. Ann Arbor, MI: NPP Books.

Mayer ML, Westbrook GL (1987) Permeation and block of $N$-methyl-Daspartic acid receptor channels by divalent cations in mouse cultured central neurones. J Physiol (Lond) 394:501-527.

McBain CJ, Mayer ML (1994) N-methyl-D-aspartic acid receptor structure and function. Physiol Rev 74:723-760.

Michaels RL, Rothman SM (1990) Glutamate neurotoxicity in vitro: antagonist pharmacology and intracellular calcium concentrations. J Neurosci 10:283-292.

Murphy SN, Thayer SA, Miller RJ (1987) The effects of excitatory amino acids on intracellular calcium in single mouse striatal neurons in vitro. J Neurosci 7:4145-4158.

Neher E, Augustine GJ (1992) Calcium gradients and buffers in bovine chromaffin cells. J Physiol (Lond) 450:273-301.

Nicholls DG, Ferguson SJ (1992) Ion transport across energy-conserving membranes. In: Bioenergetics 2, pp 23-37. San Diego: Academic.

Ogura A, Miyamoto M, Kudo Y (1988) Neuronal death in vitro: parallelism between survivability of hippocampal neurones and sustained elevation of cytosolic $\mathrm{Ca}^{2+}$ after exposure to glutamate receptor agonist. Exp Brain Res 73:447-458.

Petrozzino JJ, Pozzo Miller LD, Connor JA (1995) Micromolar $\mathrm{Ca}^{2+}$ transients in dendritic spines of hippocampal pyramidal neurons in brain slice. Neuron 14:1223-1231.

Pusch M, Neher E (1988) Rates of diffusional exchange between small cells and a measuring patch pipette. Pflügers Arch 411:204-211.

Rajdev S, Reynolds IJ (1993) Calcium green-5N, a novel fluorescent probe for monitoring high intracellular free $\mathrm{Ca}^{2+}$ concentrations associated with glutamate excitotoxicity in cultured rat brain neurons. Neurosci Lett 162:149-152.

Randall RD, Thayer SA (1992) Glutamate-induced calcium transient triggers delayed calcium overload and neurotoxicity in rat hippocampal neurons. J Neurosci 12:1882-1895.

Regehr WG, Atluri PP (1995) Calcium transients in cerebellar granule cell presynaptic terminals. Biophys J 68:2156-2170.

Roe MW, Lemasters JJ, Herman B (1990) Assessment of fura-2 for measurements of cytosolic free calcium. Cell Calcium 11:63-73.

Rose K, Goldberg MP, Choi DW (1993) Cytotoxicity in murine cortical cell culture. In: In vitro biological methods. Methods in toxicology (Tyson CA, Frazier JM, eds), pp 46-60. San Diego: Academic.

Rothman SM (1985) The neurotoxicity of excitatory amino acids is produced by passive chloride influx. J Neurosci 5:1483-1489.

Rothman SM, Olney JW (1986) Glutamate and the pathophysiology of hypoxic-ischemic brain damage. Ann Neurol 19:105-111. 
Rothman SM, Thurston JH, Hauhart RE (1987) Delayed neurotoxicity of excitatory amino acids in vitro. Neuroscience 22:471-480.

Sala F, Hernandez-Cruz A (1990) Calcium diffusion modeling in a spherical neuron. Relevance of buffering properties. Biophys J 57:313-324.

Schanne FAX, Kane AB, Young EE, Farber JL (1979) Calcium dependence of toxic cell death: a final common pathway. Science 206:700-702.

Smith SJ, Augustine GJ (1988) Calcium ions, active zones, and synaptic transmitter release. Trends Neurosci 11:458-464.

Stout AK, Li-Smerin Y, Johnson JW, Reynolds IJ (1996) Mechanisms of glutamate-stimulated $\mathrm{Mg}^{2+}$ influx and subsequent $\mathrm{Mg}^{2+}$ efflux in rat forebrain neurones in culture. J Physiol (Lond) 492:641-657.
Tsien R, Pozzan T (1989) Measurement of cytosolic free $\mathrm{Ca}^{2+}$ with Quin2. Methods Enzymol 172:230-262.

Tsien RY (1988) Fluorescence measurement and photochemical manipulation of cytosolic free calcium. Trends Neurosci 11:419-424.

Tymianski M, Charlton MP, Carlen PL, Tator CH (1993a) Secondary $\mathrm{Ca}^{2+}$ overload indicates early neuronal injury which precedes staining with viability indicators. Brain Res 607:319-323.

Tymianski M, Charlton MP, Carlen PL, Tator CH (1993b) Source specificity of early calcium neurotoxicity in cultured embryonic spinal neurons. J Neurosci 13:2085-2104.

Zhao M, Hollingworth S, Baylor SM (1996) Properties of tri- and tetracarboxylate $\mathrm{Ca}^{2+}$ indicators in frog skeletal muscle fibers. Biophys $\mathbf{J}$ 70:896-916. 